\title{
Understanding Export Led Growth and Late Industrialisation to Explain the Differences in the Post Reform Performance of India and China
}

\author{
Sebastian Morris
}

WP No. 2005/03/02

March 2005

The main objective of the working paper series of the IIMA is to help faculty members to test out their research findings at the pre-publication stage

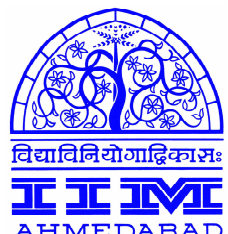

Indian Institute of Management

Ahmedabad

INDIA 


\section{Understanding Export Led Growth and Late Industrialisation to Explain the Differences in the Post Reform Performance of India and China ${ }^{1}$ Sebastian Morris ${ }^{2}$}

Both India and China began to reform in the early eighties, with the Indian reforms being very slow until 1991-92 after which they 'take-off' While there are many differences the crucial difference is that China adopted the same export led growth (ELG) policies of the successful East Asian economies - South Korea, Taiwan, Singapore, Hong Kong and Thailand, while Indian policies have been distinctly laissezfaire.

Orthodoxy's false understanding of ELG (the East Asian trade strategy), which was as far from laissez faire as can be imagined, is the root cause of the failure of other diversified economies in their pursuit of open door policies. Purposeful and massive under valuation of their currency was part of the East Asian strategy, which while making the ratio of exportables to importables close to their international prices, provided for simultaneous export growth and import substitution; something not possible in orthodoxy's standard work horse -the $2 \times 2 \times 2$ model of international trade. Simultaneous import substitution and export production is theoretically possible for economies with idle resources, with the introduction of third non-traded goods sector. ELG can therefore with compatible with little or no protectionism. This aspect of the East Asian trade (and development) strategy has been poorly understood even by the structuralists who otherwise (on the aspect of the state's involvement) had demolished the liberal laissez-faire thesis.

India's reforms have resulted in considerable discrimination against the manufacturing enterprises. Exports have grown far more slowly than was otherwise possible. The more equal distribution of income in China, and the differences in the macroeconomic policies explain most of the other observed performance differences between the two countries on aspects such as the inward flow of FDI, investment, savings, growth of particular industries. Some of he crucial dimensions of the macroeconomic policies consistent with ELG in the context of China are brought out. These are structural undervaluation of the currency, expansionary monetary policy and exchange rate targeting with only one way openness to the capital account, if at all. The character of FDI itself, which differs sharply between the two countries is related to the differences in the macro economic policies. The Chinese and the East Asian success extends the notion of 'late industrialisation' to one where external demand (along with domestic demand) is realised for the high speed expansion of manufacturing ELG. The supply side of the same strategy is build on exploiting 'idle' and underutilised labour which alone is capable of generating the vast gains from

\footnotetext{
${ }^{1}$ Paper presented at the INDIA-CHINA Conference at the Indira Gandhi Institute of Development Research, Mumbai (IIMA mimeo, January $7^{\text {th }}$, 2005), on $24^{\text {th }}$ February, 2005. The conceptualisation is from Morris, S. "Why Not Push for 9\% Growth", Economic and Political Weekly, May 17-24, pp.1153-1165, 1997. The current paper makes the same basic point of export led growth and links the understanding to the macroeconomic policies that are consistent with the same using China and India as examples of export led growth and (moving towards) laissez faire economies.

${ }^{2}$ Prof. Indian Institute of Management, Ahmedabad 380015. email: morris@iimahd.ernet.in
} 
trade. Standard models gains from trade are incomparable small in relation. A significant part of the gains do accrue to the destination countries in the from of falling prices so that there are few political difficulties in the pursuit of ELG even by large countries like China. Thus ELG is more akin to a Lewisian process that employs previously underemployed labour for tradables goods production with rising (to high level) investment rates. India is more than ripe for ELG. It can ignore the lessons from the Chinese experience only at much cost to its growth. High growth in excess of $9 \%$ is possible with ELG since even with conservatism it is achieving 6+\%. This paper also argues that the mistaken pursuit of laissez-faire as being export led growth in India would only result in the further hollowing out of manufacturing.

\section{INTRODUCTION}

The thesis that open economies (LDCs) have grown faster than those less open, which the World Bank [WB, 1987] has been pushing, has unfortunately been rejected by many radical scholars as well as by others inclined to structuralist leanings. Actually, the thesis is stronger than what studies thus far have shown. The first clarity is to understand openness as essentially trade openness. Two way openness on the capital a/c for LDCs remains a dysfunctionality and the cause of much of the balance of payments and macroeconomic volatility. Openness ${ }^{3}$ of economies is a function of the structural features, principally its population, per capita income, and land man ratio, which factors can explain as much as $70 \%$ of the variation in the ratio in large cross country studies over many years [Morris, Sebastian, 1993]. This is intuitively obvious since trade is more 'boundary' like, whereas GDP is body like, so that the openness would decline with country size ${ }^{4}$. The deviation of the actual openness from the structurally determined (fitted) openness, which is the true measure of the policy determined openness best explains the differential growth rate across countries, especially Asian. Yet the thesis does not support laissez faire, with neutral trade regimes which liberal scholars like Bhagwati [1988] and others, and the WB/IMF have been arguing ad nauseum, but instead strong intervention by the state, and a policy that creates purposeful disequilibrium. Such disequilibrium, in open (East Asian) economies has given a strong and sustained impetus to the faster growth of tradables sector and to growth itself. The argument that the strong and efficient state in the East Asian countries was crucial to their industrial transformation has been the principal plank on which structuralists have attacked the neoclassical position

\footnotetext{
${ }^{3}$ Defined as ratio of (exports+imports)/GDP.

${ }^{4}$ This can be intuitively understood in many ways: Thus if two countries merge then the cross border trade between the two now becomes internal to the merged country, while the GDP of the merged entity in an accounting sense is unaffected. Therefore the trade ratio or openness for the merged (larger) entity becomes smaller. Similarly if we consider countries to have uniform population densities and uniform levels of economic activity per unit of land (an idealisation) then the amount of interaction between two infinitesimal units of land (or economic activity) is most simply the product of the value of the economic activities. And if the friction of distance is considered then there is the additional factor of an inverse dependence on the distance (actually distance to a power close to 2). This when integrated leads to the gravity law of interaction. The gravity rule is the only rule that is in consonance with the known patterns of the volume of trade. Other theories of trade including the factor proportions and the new trade theories based on differentiated goods only seem to work because of an underlying gravity like rule which gets in, in any attempt to use them in empirical studies.
} 
of laissez-faire, and successfully, demolished the same. The micro and sectoral evidence that the state intervened in various ways picking winners, creating the appropriate price incentives for technological development and for exports, sequencing the industrialisation process, influencing the investment decisions of corporates and the chaebols (in Korea), selected and directed credit, state investments in 'leading sectors', import substitution, planning and in not merely creating the basic conditions of growth (literacy), has been too strong for the laissez faire in the sense of little or no state intervention in industrial policy ("specific" intervention) to stand up. See for instance Alam, Shahid (1989) for an early synthesis.

\section{THE ARGUMENT OF LAISSEZ FAIRE}

The East Asian Miracle Report [World Bank, 1993], is the latest in the line of laissez-faire arguments, that little else other than stable macroeconomic policies, neutral trade regimes, investments in certain social over head capital like education, have brought about the fast growth of East Asia. The debate on the Report in the World Development [Vol.22. No.4], again demolishes much of the evidence and the interpretation, and makes a case for state intervention, and industrial policy including micro-intervention. Yet the "Miracle Report" brought out a particular contention that was not answered in the debate that followed. See Lall, Sanjaya (1994) in the same discussion of the "Miracle" Report, and John Page (1994)'s reactions.

The liberal thesis argued that there is a trade-off between export promotion and import substitution, since a significant export promotion would discriminate against import goods production in almost conventional trade theory models. And, hence, that real export promotion has actually meant liberal policies, without a bias in favour of either imports goods or export goods. They point to the fact that in most of the fast growing east Asian economies, the relative price of exportables to importables $\left(\boldsymbol{P}_{x} / \boldsymbol{P}_{\boldsymbol{m}}\right)$ was close to their international prices. Using this conceptual vantage point they 'explained' the many interventions as in the aggregate being neutral since the empirical observation of $\boldsymbol{P}_{d} \boldsymbol{P}_{\boldsymbol{m}}$ being close to the international values could not be squared any other way. Hence they would argue that export promotion in fact amounts to neutral trade policies, and a movement from policies (tariffs and quota restrictions) that favour import substitution, to neutral policies is indeed a movement to export promotion. That is export promotion is nothing more than a return to laissez faire.

\section{EXPORT LED GROWTH}

We show that there is another interpretation to the East Asian (including China now) trade strategy, which "appears" to be neutral to orthodoxy. While the strong and dirigistic state argument is valid, it may be of less relevance outside the political and cultural context of Korea (and Japan). The similarity of the trade strategies of Korea, Thailand, Taiwan, China, and possibly Malaysia and Indonesia, despite their obvious differences in the state structure, industrial structure, and political systems etc., means that trade strategy should be the principal focus of attention. Especially so, when there is the desire to not merely understand their success but to emulate the same. 
While the fact that in the East Asian case $\boldsymbol{P}_{x} / \boldsymbol{P}_{\boldsymbol{m}}$ is close to the international levels is no doubt true, the interpretation is entirely incorrect being based on the limitations of the $2 \times 2 \times 2$ ( 2 factor, 2 country, 2 commodity) model of international trade. While the assumptions of two countries and two factors are not too severe an abstraction, the two commodity assumption ${ }^{5}$ is. The recognition that $\boldsymbol{P}_{\boldsymbol{m}}$ and $\boldsymbol{P}_{\boldsymbol{x}}$ can both be made large in relation to $\boldsymbol{P}_{\boldsymbol{n}}$, the price of non-tradables, opens the theoretical possibility within conventional trade theory of simultaneous import substitution and export promotion, even as the ratio $\boldsymbol{P}_{x} / \boldsymbol{P}_{m}$ is maintained close to its international value. Thus outside the restrictive two commodity world, increased openness is not because of laissez faire but because of a purposeful disequilibrium that gives a boost to tradables production at the cost of non-tradables. Moreover, if non-tradables are price inelastic for domestic consumers, and tradables are elastic (exports would face highly elastic demand being oriented to international markets), shifting resources from non-tradables in a situation of less than full utilisation of resources can lead to great gains from trade. And these can be far in excess of what conventional theory would recognise. This insight was implicit in many empirical studies of the East Asian economies, especially of Taiwan and South Korea, in their phases of transformation. Since 1978, the Chinese policy makers have been playing the game, of disequilibrium export promotion to the great benefit of their economy. The Chinese economy, starting with a low openness ratio, raced ahead under the open door policy ${ }^{6}$, and China became more open than India (a smaller economy), and is today significantly more open than what its structural parameters alone would have determined. India in contrast is less open than what it should be, and even the corrections since the liberalisation have not raised Indian openness to cross its structural value, not to speak of being anywhere near the Chinese levels.

\section{THREE SECTOR MODEL}

In a world of three commodities where the transformation of non-tradables into tradables in possible with the passage of time, we may think of trade and exchange rate policy as determining the point of production on a three dimensional production possibility frontier as in Fig. 1. Conventional free trade policy can be represented as point "F", with the relative vertical height of the curve that includes " $F$ ", being largely dependent upon structural features of the economy. Import substitution with " $\mathrm{t}$ " as the bias in favour of import competing goods as "I". Here of course as in conventional arguments there cannot be import substitution without discrimination against exports, and vice versa. India's strategy till recently implied a point such as "I", so that right through the Mahalanobis period up to the mid-eighties, the discrimination against exports were severe. Indeed in having a strong (and simple) import substitution programme, with overvalued exchange rates, the point "I" shifts to "I'", so that openness declines, and the

\footnotetext{
${ }^{5}$ With multiple commodities, and full utilisation of resources, and all of them being considered as tradeable the law of comparative advantage becomes a limited statement that, if $P_{i} / P_{i}{ }^{w}>P_{j} / P_{j}{ }^{w}$; where the prices are at autarky for the country and the rest of the world $(w)$, then the country will export $\operatorname{good} j$ if it exports $i$, and import $i$ if it imports $j$.

${ }^{6}$ Promotion of National Trading Corporations, State level trading corporations which had strong and unimaginably large incentives to export, significant and periodic depreciation of the currency, and a dual exchange rate in the early phase was all part of the open door policy which are not widely recognised. [Sung, Yun-Wing, 1991].
} 
full potential of the economy to bring into use idle resources (manpower) is retarded. The realised growth is smaller than the productive potential of the economy. In the WB sense movement from "I" " to "F" represents export promotion, and indeed it is so in the limited sense that the bias against exports is reduced. ${ }^{7}$

But export promotion (and import substitution) of the east Asian variety is an altogether different thing. We may represent it as the movement form " $F$ " to " $E$ ", via a point like "I"" in the early phase, when rapid and (forced) diversification of the economy takes place. At "E" $\boldsymbol{P}_{\boldsymbol{x}} / \boldsymbol{P}_{\boldsymbol{m}}$ could well be close to its international value even as $\boldsymbol{P}_{\boldsymbol{x}}, \boldsymbol{P}_{\boldsymbol{m}} / \boldsymbol{P}_{\boldsymbol{n} t}$ is large, giving strong incentives to the production of both import and export goods. What determines the movement from " $F$ " to "E" ? Besides, a purposive undervaluation of the currency, and dual exchange rates, there are institutional and other mechanisms that have driven real economies to "E". They include targeted exports through specially set up corporations as in China or through the chaebol as in Korea, punitive measures against enterprises failing in meeting their export targets, selective provision of credit, promotion of special export zones, special incentives for transnational corporations (TNCs) and large buying houses to locate offshore production in the country and, or make purchases from local firms.

It goes without saying that the movement from " $F$ " to " $E$ " is possible only for those economies with a diversified industrial sector, and with little skills constraint, and the ability to retain surpluses. For African economies with poorly diversified economies, an undervalued currency can only lead to terms of trade losses. Similarly, for many of the Latin American countries, wherein capital flight is endemic and structural, the benefits of point "E", would not be retained by the domestic economy, since the enhanced profits from tradables production would go out as capital flight.

\section{IMPORT SUBSITUTION IS NECESSARY FOR EXPORT LED GROWTH}

The one intellectual failure of the Mahalanobis Plan and of Planning in India was export pessimism, because given the early diversification of the economy a movement from "F" to "E" via "I" was eminently possible, but was never pursued. Politically a depreciation (or in a regime of fixed exchange rates a devaluation), not to speak of a deep under valuation of the currency has been a problem for India, due to the strong opposition from the left and the middle classes. The inflationary potential of depreciation has been their primary concern. No doubt such a danger has been highly exaggerated. If the underlying growth rate that is achievable is high enough then the inflationary potential is attenuated. Moreover if resources are not fully utilised at "F" or "I", the inflation at a point such as " $E$ " is much less than what simple monetarist dogma would imply. Idle resources at "E" or "I" would imply that the movement to "E" need not involve much sacrifice of non-tradable. In other words the vertical slope on the surface at a section

\footnotetext{
${ }^{7}$ So severe was the bias against exports with the ushering in of import substitution under the Mahalanobis Plan that, India from being the second largest exporter of textiles in world markets (about 18\% share), reached a level of less than $1 \%$ in the course of five six years . Of course the limitations of the textile policy were partly responsible, but in many other products too India lost its markets. [Singh, Manmohan, 1964].
} 
contained by the latitudes at " $F$ " and " $E$ " is quite small for densely populated economies, when they start on their transformation phase: Any additional external demand serves to utilise idle resources more than competing resources. In this scheme of things the gains from trade are far more than what conventional equilibrium theory would lead us to believe. This is intuitively obvious since if a society has idle manpower, usage of the same even under declining terms of $\operatorname{trade}^{8}$ is a positive gain ${ }^{9}$, as long as the income terms of trade for that activity rises faster than costs (particularly wage rates).

Nearly all the East Asian economies, especially Japan, Korea and China had significant incomes policy which sought to restrict immediate consumption among skilled and ordinary workers, because the wages of such workers tend to rise very fast during the transformation. A delay of the consumption spending arising out of current increases in income by as much as three years virtually negates the effect of rising incomes upon inflation and considerably enhances the resources for investment, and helps to realise the benefits of disequilibrium, without "overheating" the economy.

\section{DYNAMIC COMPARATIVE ADVANTAGE DEFINED}

Export, import goods and non-tradable, are not to be seen as given once for all. The very essence of growth is the realisation of dynamic comparative advantage. Taking the case of Korea since 1960, the initial export goods were natural resource based products: plywood, forest and agricultural products, whereas the import goods manufactures largely simple capital goods, and some consumer durables. In a few years the principal export goods were the labour intensive manufactures: shoes, toys, garments etc. These were joined by capital goods and later by scale intensive capital goods and now high tech goods. Imports of natural resources of all kinds including the materials for industrial development have grown. Today imports include simple manufactures as labour costs have risen. Thus an ascendancy of goods from import goods to export goods and vice versa is implied in the 'forward -looking' production possibility frontier. This distinct phases in the unfoldment of the dynamic comparative advantage has been documented by many scholars. [Ozawa, 1991]. What has been less understood is that non-tradables are also mutable. There is a slow long term transformation of non-tradables into tradable. Garments for example was largely a local industry. The Great Wars created a market for mass produced uniforms, and this experience led to the ready made garments industry. As

\footnotetext{
${ }^{8}$ It is interesting that both China and Korea saw declining terms of trade, when their exports expanded fast. This terms of trade decline is the inevitable tribute that the late industrialisers pay to the already industrialised for market access. But the income terms of trade have risen sharply. It is quite likely that if the terms of trade does not fall in the initial phases of expansion of manufactured goods, there may be constraints to expansive growth via cheapening through the realisation of scale economies and learning. Both groups of countries gain, because idle resources are used up in the exporting country.

${ }^{9}$ The corollary of this argument is that forced free trade in an economy that does not yet have a basic minimum of industries and is still only exporting natural resource based products, would tie its fortune to the limitations in its endowment of natural resources and to growth in the external demand for the same. As the material content of GDP, world over, declines with growth, the losses in the form of the opportunities forgone to utilise a growing population productively become large. This is what happened to the densely populated non-white colonies such as India.
} 
it remained a labour intensity activity, most LDCs were in the immediate post WWII period absolutely efficient, and any country that could gear up and develop links with advance country buying agents and discount stores, could look forward to large increases in sales. Of course certain services like electricity, that of roads and railways, haircuts, etc are strict non-tradables, so that an infeasible region on the 'dynamic' production possibility surface is obvious.

There are major positive externalities in moving from " $\mathrm{F}$ " to " $\mathrm{E}$ ", since the vast increases in export goods takes place along a learning curve, and in many goods there are significant scale and scope economies too. The de facto 'subsidisation' at "E" (unlike most other subsidies to industry) has the merit of being self subject to the discipline of the international market. Given the competition between nation states the international market can be assumed to be most competitive for the price sensitive goods that are the initial (for quite a while) export goods of a densely populated transforming economy. International competition acts to weed out the inefficient and those who cannot adapt. The import substitution that take place at "E" is at low level, if any, of protection, and creates fewer opportunities for rent seeking ${ }^{10}$. The problem of lobbies emerging to hold on to tariffs or explicit subsidies is not there. Indeed many industries which may have started off being protected could be coaxed to give up protection as the periodic rounds of nominal depreciation that are necessary to maintain the undervaluation of the currency take place.

\section{THE KEY EVIDENCE}

The evidence in support of the hypothesis that the east Asian economies have in their transformation phases followed a strategy of undervalued exchange rates, is difficult to assemble. The usual measure of under/over valuation of the currency refers to deviations from the market/ black market rates of the currency, which are contingent upon the trade regime itself. Thus economies with highly restrictive and tightly administered import regimes would show much less overvaluation than others with looser import controls. Moreover, under/overvaluation as conventionally understood reflects a disequilibrium in the short term demand and supply of foreign currency, which has little to do with the ratio of tradables to non-tradables prices. The PPP measure of GDP suggests itself naturally. Yet there is a direct and systematic dependence of the PPP factor (exchange rate GDP/PPP GDP) upon structural features of the economy including the level of its development. The PPP factor tends to be smaller the poorer the economy.

Regressing ${ }^{11}$ the PPP factor (as a percentage) on these structural measures, the residuals are a true measure of the policy induced purposeful disequilibrium in the exchange rate. These residuals present a most interesting picture. See Fig.2, which plots the residuals for some of the East-Asian Economies and India. For Indonesia, China

\footnotetext{
${ }^{10}$ Where there are severe import quotas (specific for particular source countries as in the case of garments) at the destinations, and the source country has very large factor cost advantage, as in the case of India, rent seeking, in allotment of export quotas have emerged.

${ }^{11}$ The data covered the period from 1950 to 1988, for about 130 countries. In all 3292 data points with non-missing values were used in panel form. The structural factors included population, share of consumption and investment expenditures, per-capita income in log log form. The F-ratio for the regression was 708.5 and the adjusted R sq. 0.6593 . The data was from the Penn World Tables, Mark V. [NBER, 1991].
} 
(since the Open Door Policy), Malaysia, Thailand and Korea (up to 1980, by which time it had carried out its industrial transformation), the residuals are all negative, whereas for India it has been positive and have hovered around zero during the eighties. The periods of rising openness match the periods of large negative values for the residuals. China's movement from "I" or "I"" to "E" has been quick and dramatic with exports (and imports) increasing by leaps and bounds. Malaysia, Indonesia and Thailand since the mid seventies show the same pattern that Korea showed during its transformation phase. The residuals could not be computed for Taiwan because many of the data was not available. Furthermore, the movement of exchange rates of these countries shows the deep devaluations/ deprecations that were periodically carried out. In contrast the devaluations/ depreciation of the Indian currency has been rather modest. Even after adjusting for inflation rates we do find a major difference between these countries and India.

\section{SOME IMPLICATIONS}

Monetarist theory believes in the law of one price (viz that: the price level, the nominal interest rate, and the exchange rate would adjust to make the real interest rate equal the social time preference, and the exchange rate to purchasing power parity). Empirical evidence suggests that the period over which prices adjust is as long as 16 quarters. This is too long for a fast growing economy. And interest rates can remain far from any meaningful social rate of discount for too long. Similarly, the deviation of exchange rate from the purchasing power parity is more the norm. In other words, most economies, not to speak of fast growing LDCs are in hardly in any kind of equilibrium in the classical sense. This gives rise to a major role for strategic macroeconomic policy, that goes beyond "stabilisation" as such. We have already seen that PPP GDP systematically deviates from exchange rate based GDP, but even after they are adjusted for certain structural features they still deviate. The Keynesian insight was that government expenditures and fiscal and monetary policy in general may be required for reducing fluctuations and to maintain output close to full employment levels. In a world of open economies actively trading with each other, this insight translates to the need for a country to purposefully undervalue its currency, if it has large undervalued resources (like labour) which are easier to exploit via tradables (esp. export goods) production.

Obviously the capacity of the economy to respond to such structural undervaluation is crucial to the success of such macro-economic policy. Import substitution and investments in education simultaneously (as in the case of East Asia other than China) and prior (as in the case of China, are crucial to creating the capacity of the manufacturing sector to respond. The response of exports in itself resulting in the exploitation of both internal and external scale economies, in vast positive spillover effects (brought out in many studies of cross country examinations of export led growth), and in feed back effects further fuels the ability of the economy to respond, so that the typical East Asian economy epitomised by China today is created whose manufacturing prowess cannot be fairly contested. Only protectionism on the part of the developed countries and either that, or the imitation of the same export led growth can work to stem the onslaught of China in the manufacturing sector today. 
The strategy is sustainable since with rise in incomes, and after manufactured goods are entrenched the dependence on undervalued exchange rates is not strictly necessary. The existence of idle /underemployed labour is crucial to the success of such strategy. It can work as long the gross labour productivity has not caught up with the levels in the advanced countries. The advanced countries in allowing in such exports gain enormously since they gain out of the declining terms of trade of the export led growth economies. These gains are stupendous. LDCs in response to East Asia have no options but to export materials when they are endowed or to stand by if they are not so endowed and let the process of development pass by for another generation. Others like India can potentially join the East Asian nations with appropriate macro policies. It is only the traditional and faulty understanding of export led growth that prevent an appropriate policy response from India. Standard models predict small gains from trade typically under $5 \%$. The empirically observed large gains from trade are consistent with our model and extend the understanding of Arthur Lewis of economic growth with unlimited supplies of labour but in the open economy context. With this understanding the relatively small share (30\%) of TFP in the total growth of output as an adverse feature of East Asian growth is quite unwarranted. When labour is idle /underutilised much of the growth would reflect itself in input growth (extensification) which alone can result in the very high growth achieved in these economies.

\section{OTHER ASPECTS OF THE MACRO-ECONOMIC POLICY}

Maintaining structurally undervalued exchange rates involves its own approach to macroeconomic policy in a world (system) of floating exchange rates. In a situation of some (inward) capital mobility monetary policy looses its autonomy. This is the insight from the Mundel-Fleming model. If we bring in the notion of response to interest rate differentials only after a certain gap has opened up, and to bunching of capital flows - i.e. to over responsive flows once flows respond, then money supply has some determination to the extent that the central bank can decide to vary the amount of inflows to sterilise. Fiscal policy of course has the major determinant if the central bank does not target money supply.

In China the macroeconomic support for ELP has meant the following

(1) Not allowing the currency to appreciate despite both capital and current a/c surpluses. This in the nineties has been achieved by pegging the currency to the dollar and managing the peg through a vast build of reserves that now exceed US\$ 500b. Earlier in the late seventies and eighties sharp depreciations to take the currency below its equilibrium values were crucial to maintaining high growth rate of exports that in dollar terms often exceeded $30 \%$ and on an average of around $20 \%$ p.a.

(2) The above means that money growth is large in relation to countries following more conventional policies of monetary targeting. (See Fig.3 and 4).

(3) Highly variable fiscal policy that targets demand when adverse external shocks hit the economy hurting exports since exchange rates are already structurally undervalued. Thus China following the global economic recession stepped up fiscal expenditures (despite mounting fiscal deficits) to keep up the demand pressure and was able to retain its high growth despite a slow down in exports. 
(4) Interest rate targeting has also meant much lower interest rates both nominal and real, though as is widely known the successful East Asian countries avoided large negative real interest rates for extended periods. It does not mean that the medium term variability in real interest rates is necessarily low. Nominal interest rates variability would be lower in China as compared to India. (See Fig.5).

(5) Such monetary policy management would necessarily result in far less sterilisation of capital inflows. (See Fig. 6.). China opened itself to portfolio flows in the late seventies itself and these have seen the usual variability. But since China has not adopted any form of capital a/c convertibility other than investment freedom to its corporates, the flows of portfolio capital have been small relative to its trade. The contrast with India is significant. In India since money is targeted rather than interest rates, the resulting deviation of domestic rates, and speculative responses to the same opens it to portfolio flow variations of a high order. This is entirely unwarranted since the marginal savings rate being higher than the realised savings there is no value in additional inflows whose only task is to make macro-economic management that much more difficult.

(6) On the whole therefore the inflows into China have been of direct investment variety. (We assume that $15-20 \%$ inflows of FDI into China are true and the rest being merely round tripping of domestic investments, since the Chinese state did not grant the right to property to its citizens but only to foreign persons legal and natural. This has changed only this year.) In India, both direct and portfolio investments have had a large speculative aspect and have done much to destabilise the investment climate for domestic players through high variations in the interest rates, in credit conditions and in lowered demand from conservative macroeconomic policies. (See Fig. 14, 12).

(7) Money growth being faster in China even in relation to its higher GDP growth, has cumulated to high levels of money stock as a proportion of GDP. The difference with India is stark. (See Figs. 3, 4, 6). With only limited openness on the capital account and with vast reserves there is no danger to the Chinese economy. But in case the Chinese were to (very foolishly) adopt capital account convertibility then the entire M1 and more, is potentially exportable in a crisis to lead to asset price deflation and a crisis. Therefore export led growth is inconsistent with open capital account (given the home country bias of international capital flows). This was amply demonstrated in the East Asian currency crisis, which hit these countries about 5-8 years after they had gone for capital account convertibility. Higher money growth in China and in ELG economies though is nowhere near the absurd growth rates that LA countries show during their hyperinflation. (Fig. 4).It is much better to understand the hyperinflation of these countries as a response to vast capital flight that is accommodated by willing central banks without much reserves by vast monetary expansion and then its continuation in an attempt to keep up the purchasing power of government and the favoured few. These policies have strong political basis, and the IMF has unwittingly or otherwise, in insisting upon 'free' capital movements contributed, to the maintenance of such perverse political economy and central bank behaviour that results in capital flight.

(8) Realised inflation in China had been somewhat higher than in India though it has declined to levels comparable or lower than that of India in recent years. This is despite higher monetary growth, which squares up with our conceptualisation of 
export led growth as exploiting the Keynesian option of demand to utilise idle or partly used resources. (See Fig. 13). In other words as long as rising expenditures result in investment rather than consumption (to keep investment rates high) the inflationary impact is not there, or is entirely manageable.

Thus while the gains from trade of standard pure trade theory models arise from comparative advantage, herein they arise from use of idle resources and so can be very large. Because export led growth result in sales increase of firms that are highly competitive, there is enough surplus that they create to win market access, and so can be beneficial to all including their destination countries. Hence protectionism in the advanced countries cannot be an insurmountable barrier to the success of ELG countries.

Another observation that ties up with the functionality of structurally undervalued exchange rate is the fact that in ELG countries FDI is directed in a far greater measure to the external market, i.e. they are in themselves export oriented to a larger degree than in countries following more conventional policies. Even more than FDI the non-equity forms take precedence in these countries - forms such as international subcontracting, original equipment manufacturing, contract production, and licensing. In contrast in Latin America and South Asia with more conventional policies the orientation of much of FDI when it is not natural resource seeking is to the domestic market. In other words in pursuing ELG policy (principally the aspect of undervalued exchange rates) the locational advantage of the country becomes very large and international and competitor capital too responds.

The puzzle of so called 'non-competitive' firms ${ }^{12}$ from India taking up plant in China to export back to India, and sourcing manufactured goods from China is therefore explained. The fact is the problem is not with these firms but with the macro policy of not being able to match Chinese currency in the undervaluation.

The extremely large manufacturing sector in China and South Korea in contrast to the more modest size of the same is also understood as arising out of the same policy.

A matter quite independent of the pursuit of export led growth in China which to large extent it shares with Korea, Taiwan and Japan is the relative equality of its income distribution. Indian income distribution despite the many studies that 'show' it to be quite egalitarian is hardly so when the market sizes of luxury goods in India are compared to that in China or South Korea. The egalitarian distributions were a handover of the previous regime and the current system has made good use of the same since there are hardly any home market constraints, or labour skill side constraints in the Chinese expansion. Its distribution though is becoming more unequal. Extremely high growth in the consumption of particular products like cars today, white good some years back ties up with this understanding. The Thai income distribution is probably some where in between.

${ }^{12}$ Examples would be Bajaj, Orpat, Hero and many others and nearly all competitive white goods manufacturers. 
To race ahead along the path of export led growth, for India would also be income distribution improving since export industries are employment intensive and exports put much income into the pockets of the poor.

Detractors would argue that India's comparative advantage lies in "services". Even if it does the service sectors are only slowly becoming tradable. A non tradables service sector cannot be taken advantage of to employ idle labour. Services even tradables services do not show the increases in per head output that manufacturing sector does and so is a feasible advantage only as long the factor cost difference is large. More importantly an advantage in services in a situation of unemployed labour in no way denies the advantage of manufacturing. Indeed India's comparative advantage in manufacturing was always very high. Its textiles at one time India commanded a $15+\%$ share of the world market. It ratio of manufactured export to import even at the time of independence was close to 1; and it was the one country that could have taken advantage of falling tariffs (under the post Bretton Woods rounds of GATT negotiations) had it not been for the export pessimism of policy in India. Even today its comparative advantage is no different from that of China. See figures 15,16 .) It is trade in goods and services that is being discriminated against as the balance on account of both manufacturing and services (until very recently) would indicate. (See Figs. 7,8, 10). The openness ratio therefore of India a smaller country than China therefore is smaller! (See Fig. 9). This is not to say that the services sector today is not an engine of growth. Indeed the export of tradables services (India's export to import ratio has overshot the Chinese in recent years. See Fig. 8) is what keeps India's growth rate at a the 6 plus percentage. This export as also the other exports of India are largely and as yet 'absolute advantage products' diamond and granite polishing, handicrafts, textiles, gems, ethnic products and software BPO, tourist and other related services, which are somewhat shielded from having to have the correct macro-economic policies. Even then India's export growth is a decent $15+\%$. With policies that bring out the export of comparative advantage products i.e. products in which India has to compete, the export growth that India can achieve is stupendous.

\section{CONCLUSIONS $^{13}$}

Orthodoxy's (limited) understanding of the East Asian trade strategy, which was as far from laissez faire as can be imagined, is the root cause of the failure of other diversified economies in their pursuit of open door policies. A purposeful and massive under valuation of their currency was part of the East Asian strategy, which while making the ratio of importable to exportable close to their international prices, provided for simultaneous export growth and import substitution; something not possible in orthodoxy's standard work horse -the $2 \times 2 \times 2$ model of international trade.

Simultaneous import substitution and export production is theoretically possible for economies with idle resources, with the introduction of third non-traded goods sector. This aspect of the East Asian trade (and development) strategy has been poorly

${ }^{13}$ Some of these arguments had been made earlier in Morris. S. (1997), Morris, S. (2003); Morris,S.(2004) 
understood by even the structuralists who otherwise demolished the liberal laissez-faire thesis.

The difference between the Chinese and the Indian performance can be explained in terms of China having followed export led growth and India since the reform as veering to laissez faire. The macroeconomic dimensions of the difference in strategy are also understood fruitfully in terms of the above.

Indian manufacturing in the situation of conventional and conservative monetary policies is bound to be further eroded, The irony is that good Indian companies are bound to source and even set up plant in China. The hollowing out of Indian manufacturing is inevitable unless policy makers appreciate the nature of export led growth as not being laissez faire but as a Keynesian approach in the international context to a Lewisian situation of surplus labour. There is something akin to the 'Dutch Disease' that is working against the manufacturing sector in the current policy orientation of the Indian state and the central bank. The vast remittance on factor account (workers remittances) gives the Indian economy somewhere in the range of US\$ 15 to $18 \mathrm{~b}$ which is the largest single item on the current account, has no offsetting outflows and is around 2\% sometimes reaching as high as $2.5 \%$ of GDP. It has allowed to central bank the luxury to price the rupee high enough to open the balance on trade in goods and services to negative levels. That (in relation to East Asia and more especially China) hurts Indian manufacturing and hence growth at high rates is missed.

The pursuit of ELG is eminently feasible in India today. The comparative advantage of India as revealed in not in doubt. (See Figs. 15 and 16). With barely 2\% percent of the world land with a population of $20 \%$ or more, there is no way India can progress without vast exports of manufactures and tradables services. This is structurally ordained so that its long term comparative advantage also coincides. One possible 'objection' could be that because of structural 'rigidities' like infrastructure and labour market 'inflexibilities' the potential to grow at higher rates is not there. The argument against such a contention is two fold. In the first instance manufacturing has grown at rates in excess of 9\% already for four years at a stretch (1993-94 to 1997-98) and shows vast capacity underutilisation today for lack of demand and overpricing of currency. Secondly the constraints have been highly exaggerated. Labour flexibility is much greater than what is believed especially in a situation of high growth that allows redeployment, and the small industry offers the greatest flexibility possible, in India. Infrastructure constraints are best addressed by exposing the limitations of the current setup with use and rising demands. In any case these are not fundamental and can be corrected, especially if and when they are exposed through high growth. Similarly the argument of savings constraint is a red herring. When the marginal rate of realised savings in higher than the average rate as is the case in India, investments can drive savings, as it does in China today and in the ELG economies of East Asia. The infrastructural constraint as it is exposed can be addressed by high levels of efficiently directed investment which itself can constitutes one of the basis for demand. Similarly the specific inflation in food prices possible is also no issue at all given the large buffer stocks of food.

A matter that needs recognition is that when the Indian economy grew at 5.75\% in the eighties it was subject to the weight of delays and cost overruns of about $50 \%$ or 
more on public sector investments which constituted about $50 \%$ of gross capital formation. These delays and cost overruns imposed a growth penalty of nearly 1.5 to $2.0 \%$ With the same having considerably reduced, since public sector investment are no more than $20 \%$ the efficiency of the Indian economy has gone up. Additional factors are the gains due to tax reform the movement away from discretionary potential the great reduction in directly unproductive activities following from the reduction in rents, a growth rate of less than $7.75 \%$ is clearly under-targeting, even if one were to go by the monetary targeting approach.

\section{References}

Alam, Shahid (1989) Governments and markets in economic development strategies; lessons from Korea, Taiwan, and Japan, New York, Praeger

Bhagwati, Jagdish (1988), "Export Promoting Trade Strategy: Issues and Evidence", The World Bank Research Observer, Vol.3, No.1, Jan.

Burgenmeier, B. \& J. L. Muchielli (eds.) (1991), "Multinationals and Europe 1992: Strategies for the Future", London and New York, Routledge.

CMIE, CIMM, Corporate Information on Magnetic Media, database of the Indian corporate sector.

Gerschenkron, Alexander (1966), "Economic Backwardness in Historical Perspective", Cambridge, Mass., Harvard Univ. Press.

Lall, Sanjaya (1994) “The East Asian 'Miracle': Does the Bell Toll for Industrial Strategy?”, World Development, April 1994, v. 22, iss. 4, pp. 645-54.

Morris, Sebastian (1992), "What is the Functional Form for Aggregate Income?", mimeo.

Morris, Sebastian (1993), "Structural Determinants of the Openness of Economies: The Conceptual Basis and Cross-Sectional Evidence”, WP No. 1130, August, Indian Institute of Management, Ahmedabad.

NBER(1991), “The Penn World Tables, Mark V: An Expanded Set of International Comparisons, 1950-1988", National Bureau of Economic Research Inc., USA; and associated article by Robert Summers and Alan Heston, of same name, also published in Quarterly Journal of Economics, May, 1991.

Ozawa, T, (1991), "Japanese Multinationals and 1992”, in Burgenmeier, B, \& J. L. Muchielli (eds.) (1991).

Page, John (1994), “The East Asian Miracle: An Introduction”, World Development, April 1994, v. 22, iss. 4, pp. 615-25 
Morris, Sebastian (1997), . "Why Not Push for 9\% Growth", Economic and Political Weekly, May 17-24, pp.1153-1165, 1997.

Morris, S. (2002) "The Challenge of Governance in India Today", Chapter 2 in Morris, S. and Rajiv Shekhar (eds.) (2002) Morris, S. and Rajiv Shekhar (eds.) (2002), "India Infrastructure Report 2002: Governance Issues for Commercialization", 3iNetwork, New Delhi, Oxford University Press.

Morris, S. (2003) "Expenditure Accountability in India: The Interlinkages" in Morris, S. (ed.) (2003), "India Infrastructure Report 2003: Public Expenditure Allocation and Accountability", 3iNetwork, New Delhi, Oxford University Press.

Morris, S. (2003) "Public Investments in India: Delays and Cost Overruns", in Morris, S. (ed.) (2003) ibid.

Morris. S. (2004) "Overview (of Ensuring Value for Money in Indian Infrastructure)", Chapter 1, in Morris, S. (ed.) (2004), "India Infrastructure Report 2004: Ensuring Value for Money”, 3iNetwork, New Delhi, Oxford University Press.

Singh, Manmohan (1964), “India's Export Trends and the Prospects for Self-Sustained Growth", Oxford, Clarendon Press.

Sung, Yu-Wing (1991), "The China - Hong Kong Connection: The Key to China's Open Door Policy”, Cambridge, Cambridge Univ. Press.

World Bank (1987), “World Development Report 1987”, World Bank and Oxford Univ. Press, Washington D.C.

World Bank (1993), "The East Asian Miracle: Economic Growth and Public Policy", Policy Research Report, Washington D.C. 
Fig.1

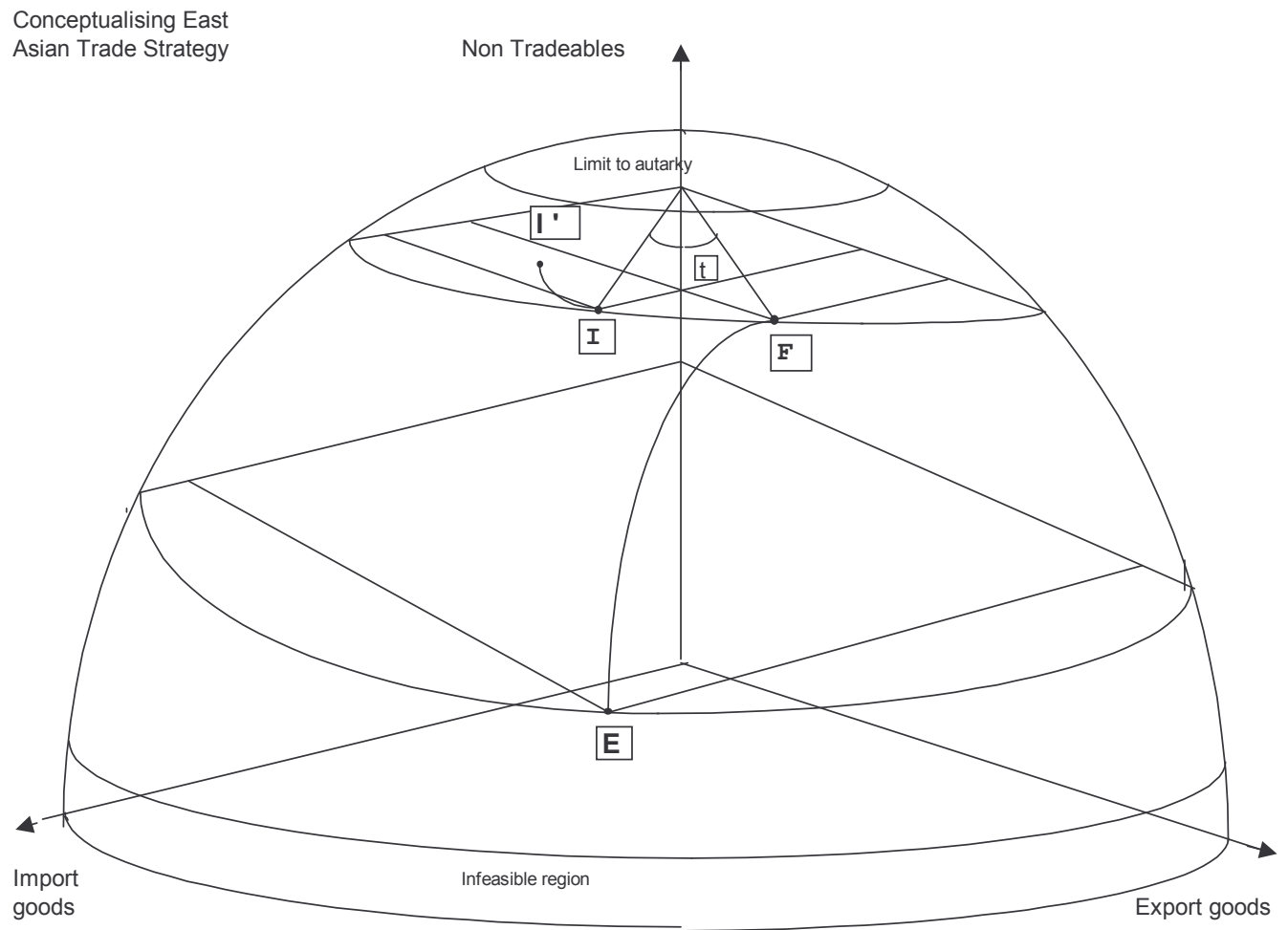


Fig.2 : Deviations of Exchange Rate GDP/PPP GDP from Structurally Determined Values

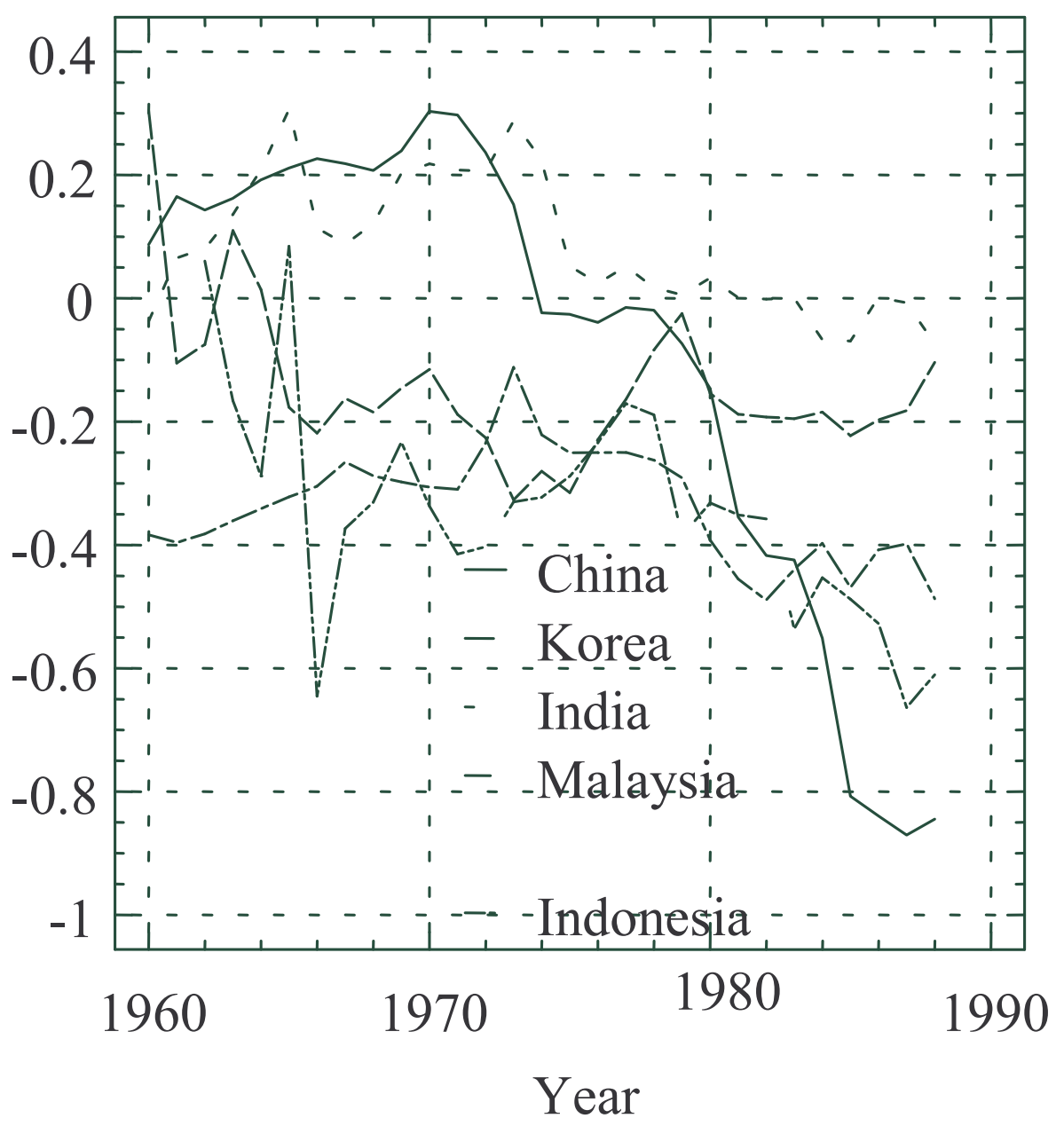


Fig. 3

Money Growth (M1) in EA, China and Indi

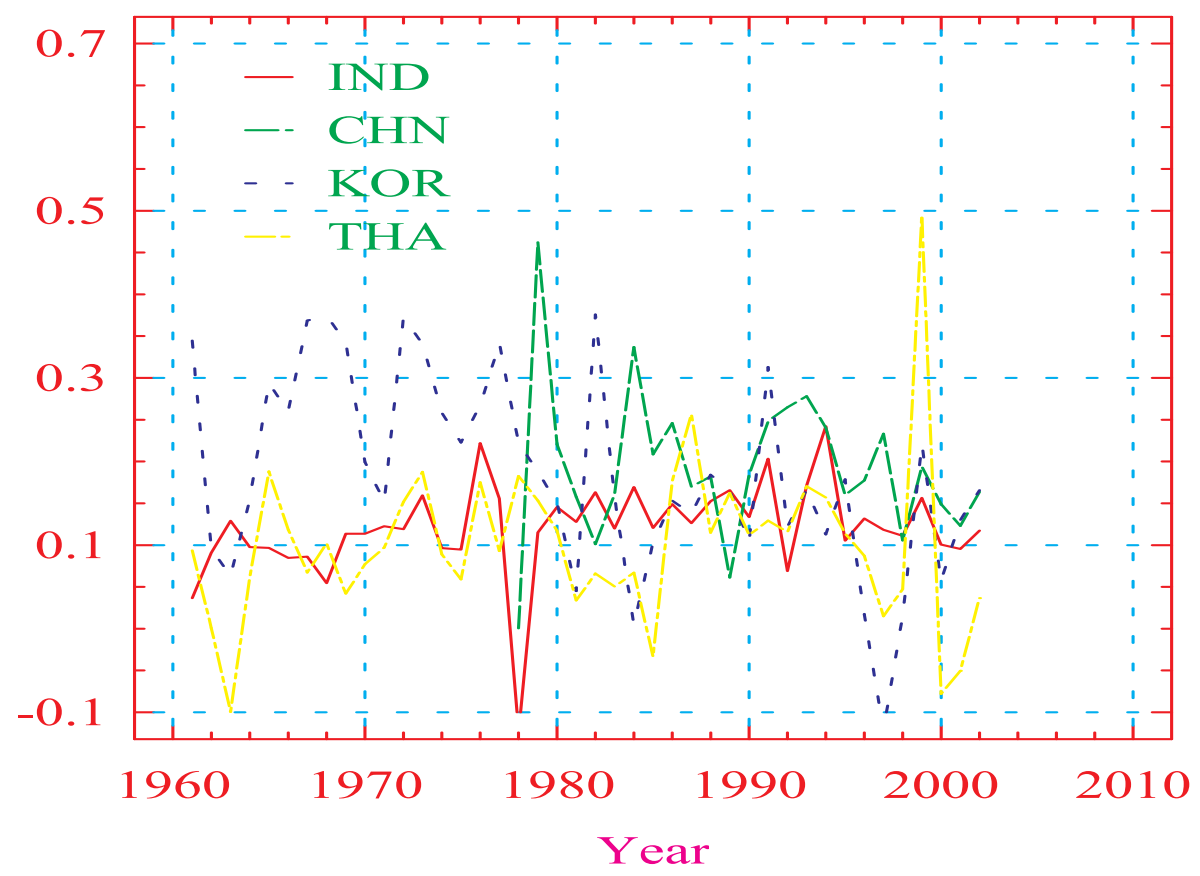

Fig. 4

M1 Growth in IND ARG BRA and CHL

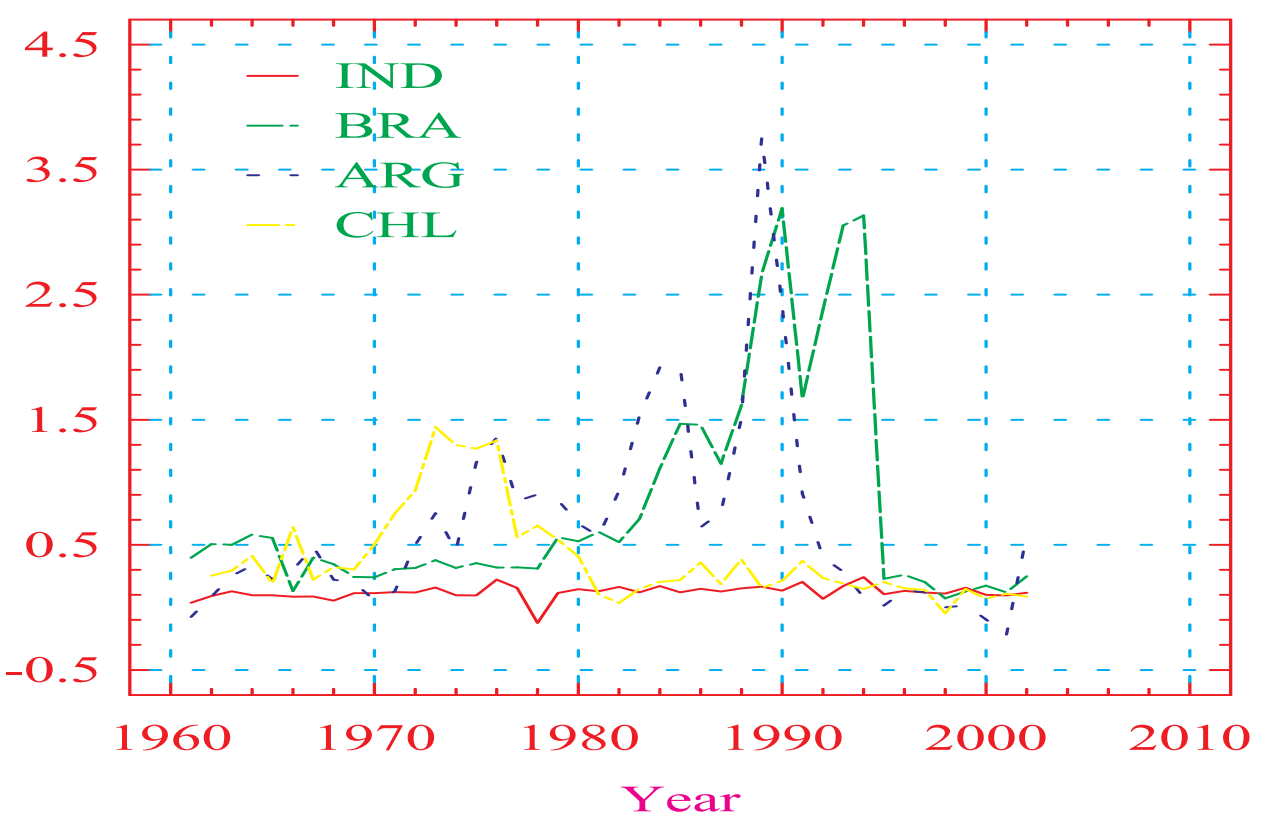


Fig. 5

Nominal Lending and Real Interest Rates (India and China)

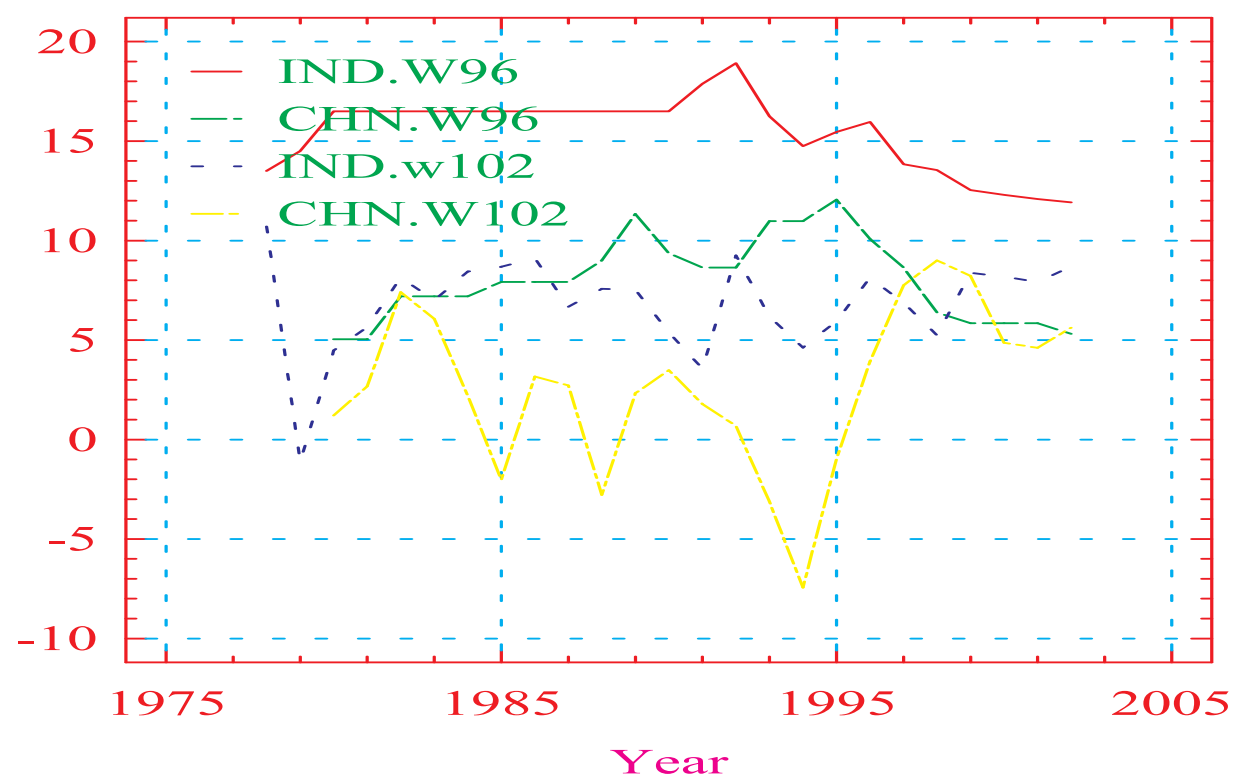

Fig. 6

M3 and Domestic Credit Provided by Banks as $\%$ of GDP (India and China)

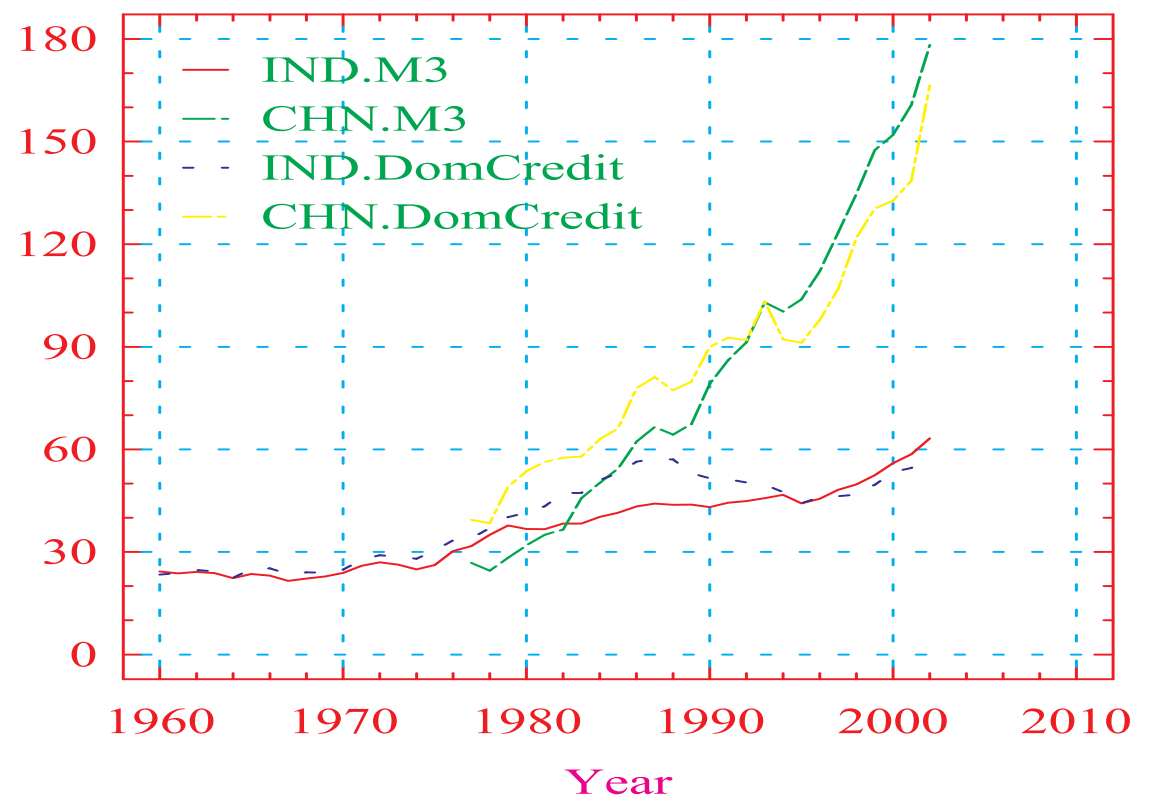


Fig. 7

Trade Gaps to Trade Volumes Ratios (India and China)

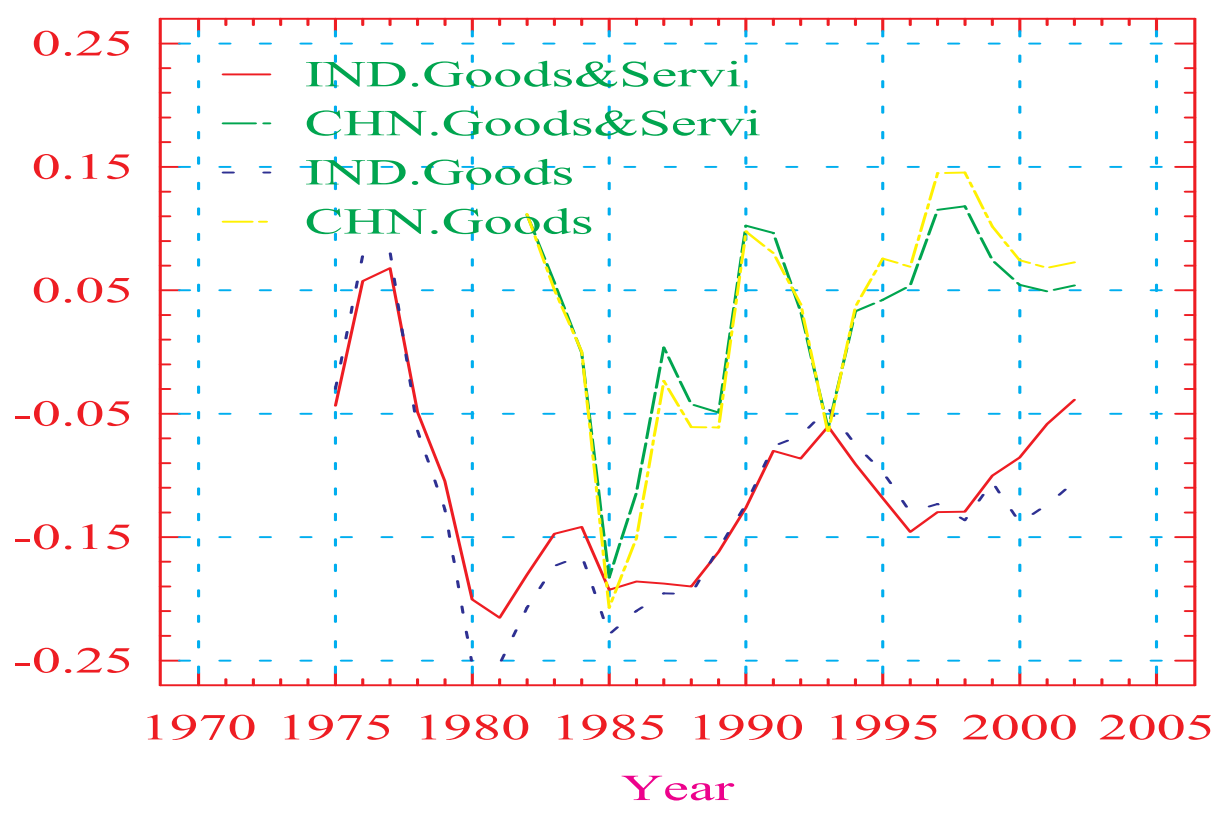

Fig. 8

Ratio of Exp to Imp (Goods, Services) (India and China)

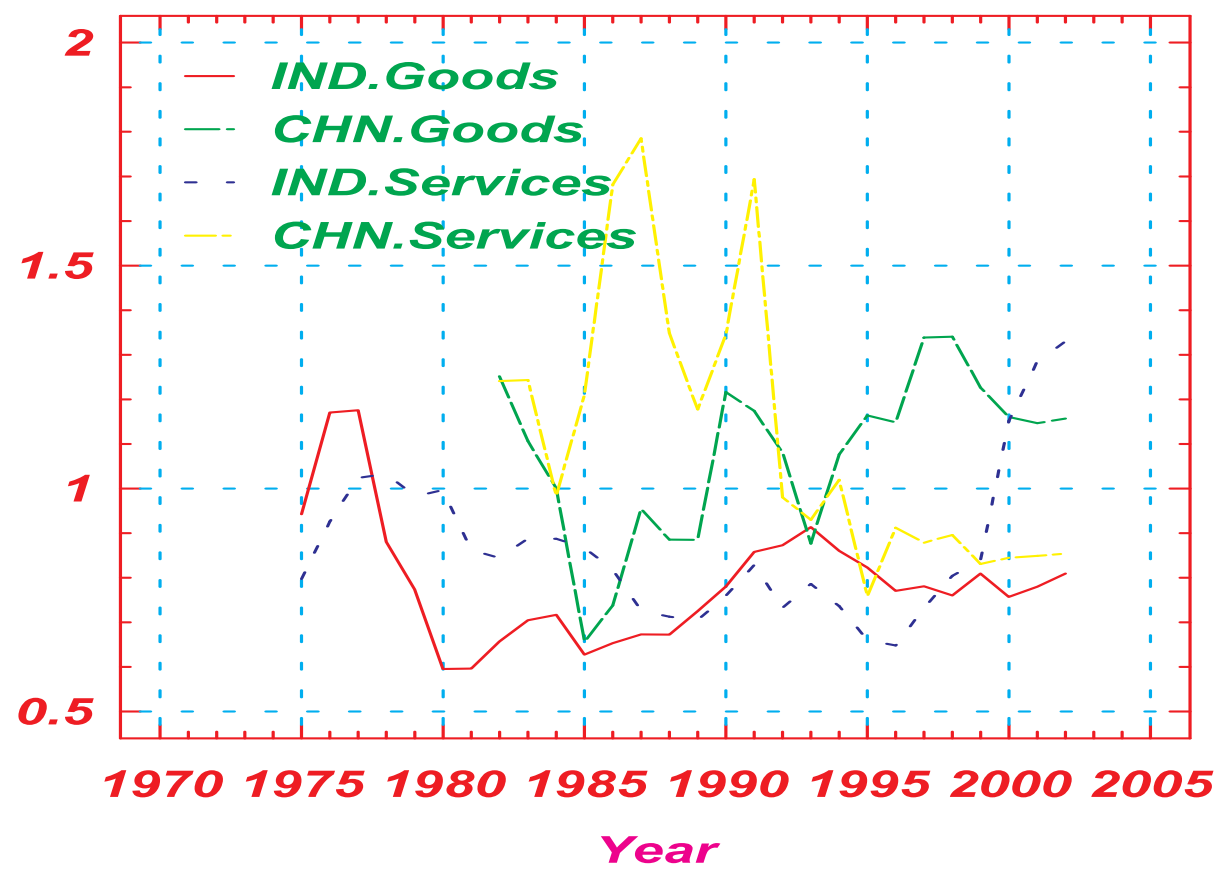


Fig. 9

Openness Ratio (Goods \& Services /GNI) (India, China, Korea and Thailand)

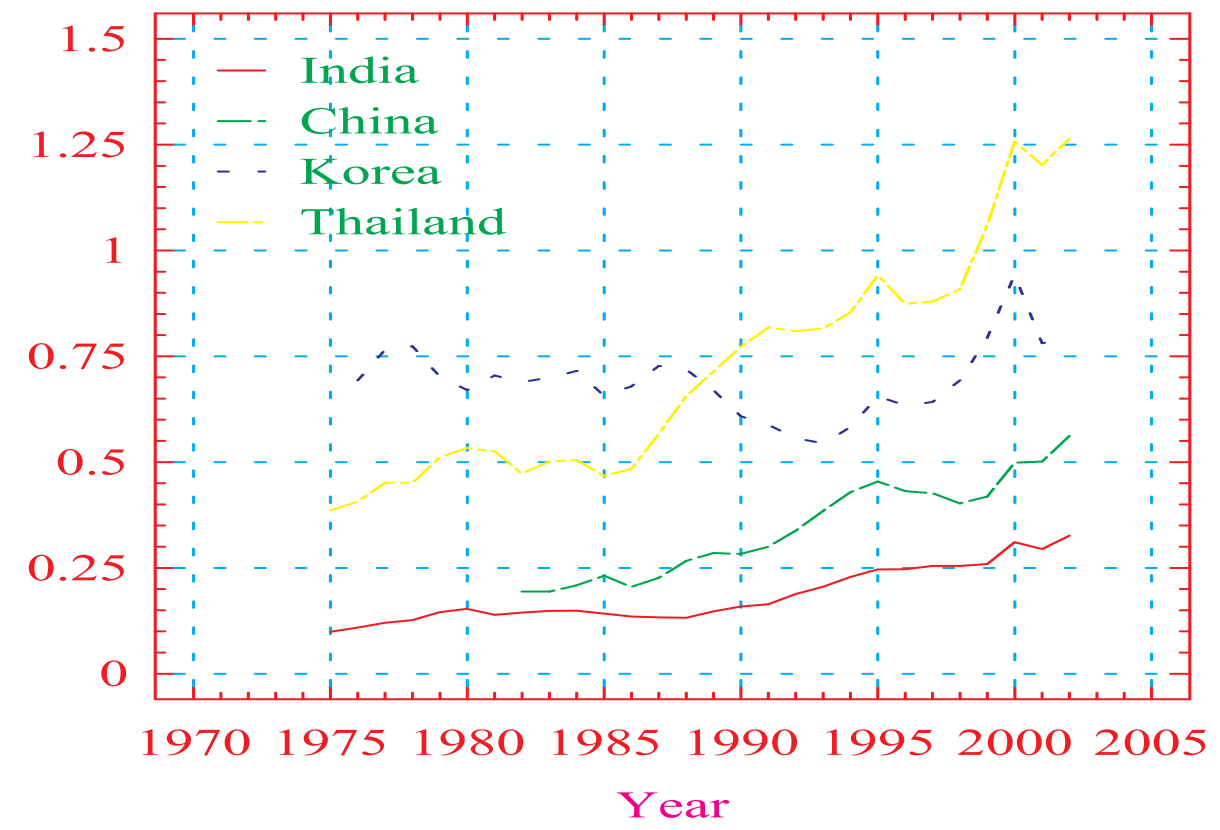

Fig. 10

Trade and C/A Balances (India and China) X 0.001 )

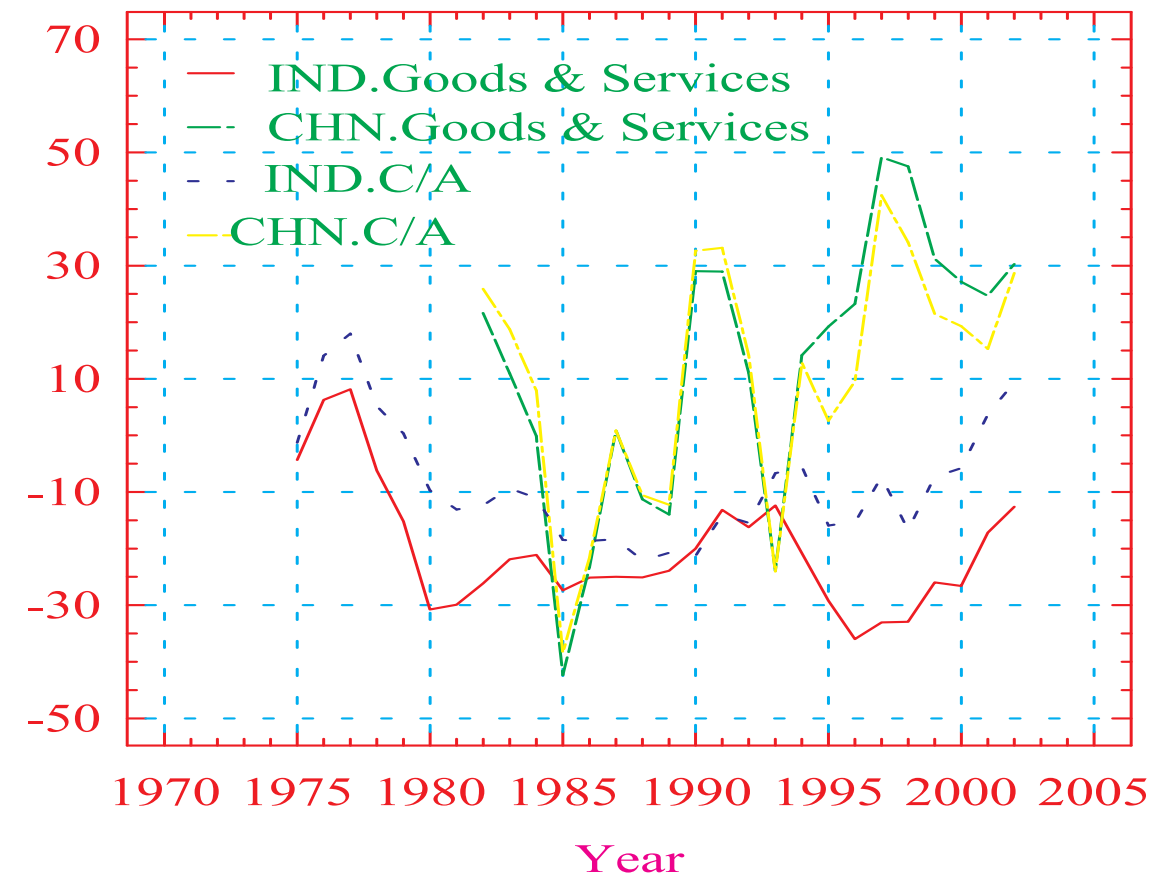


Fig. 11

Workers Remittances / GNI (India, China, Korea, Palistan)

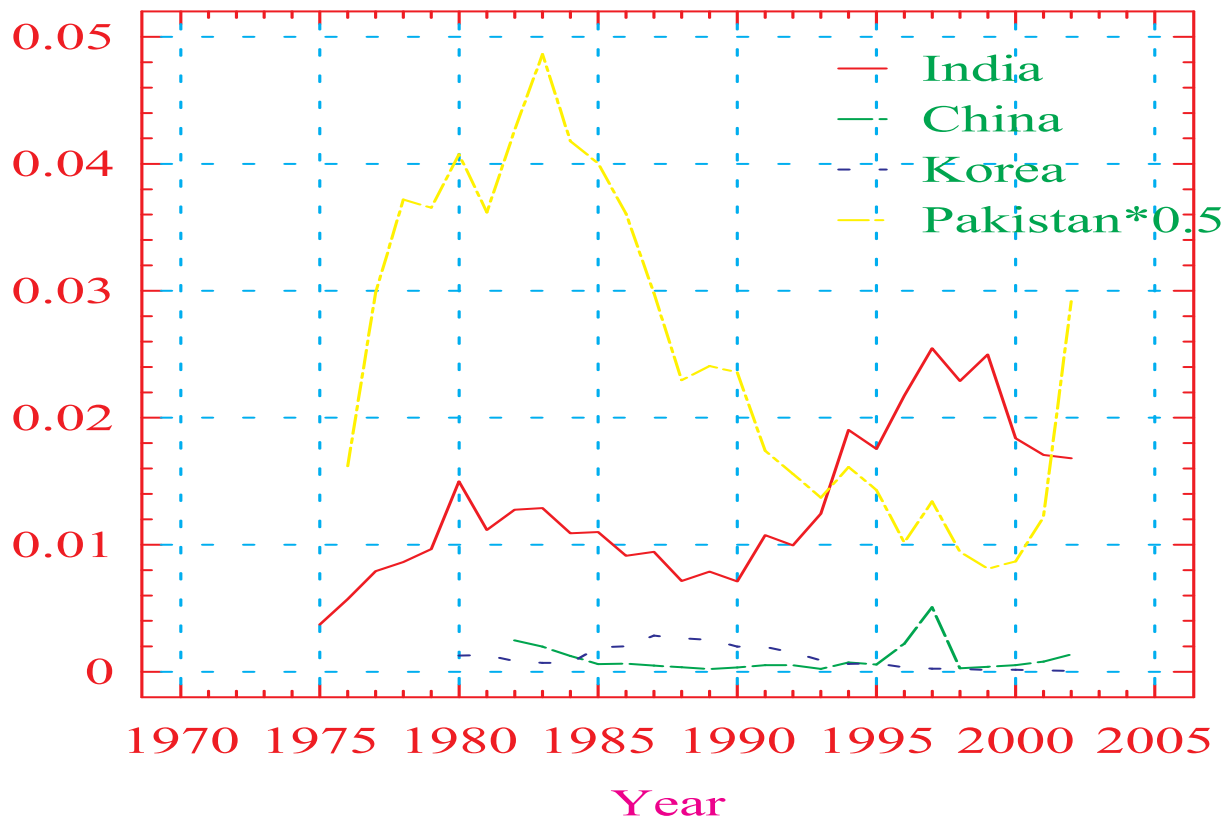

Fig. 12

Net FDI Inflows / GCF (\%)

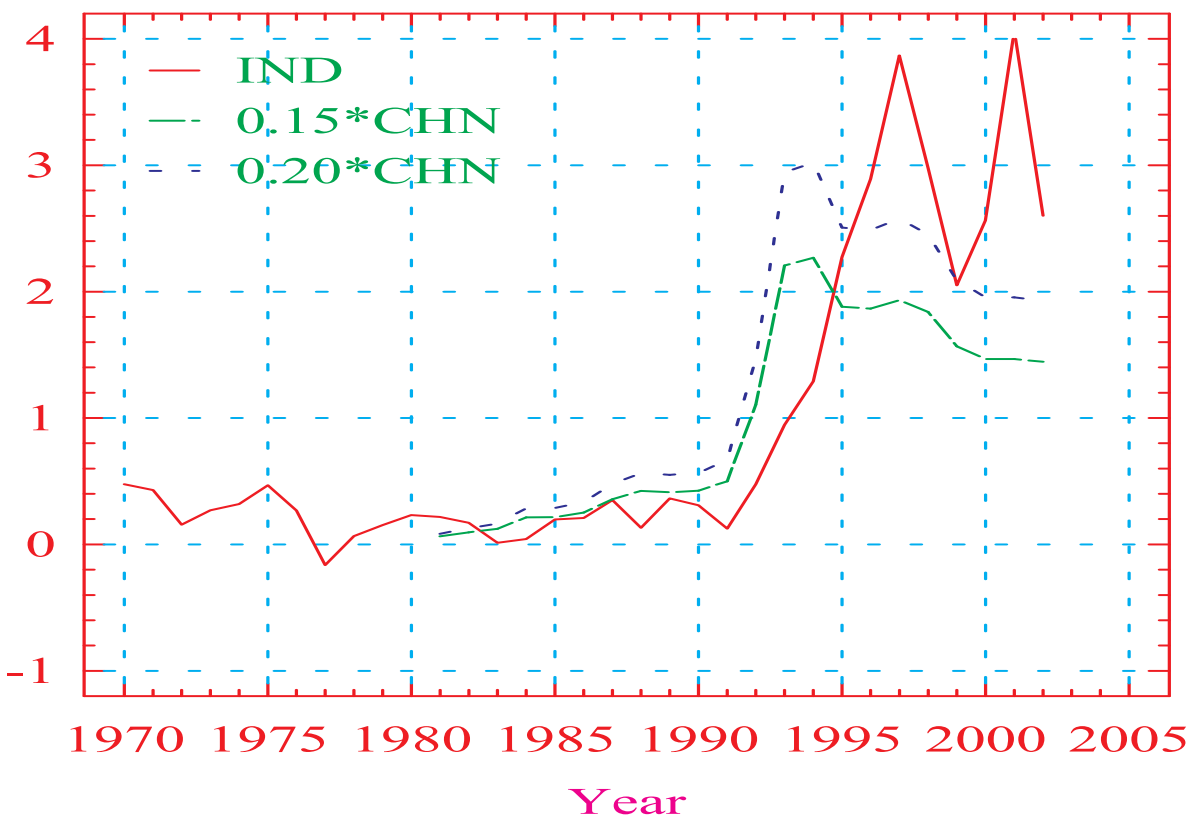


Fig. 13

\section{Inflation (GDP Defl. Based) (\% p.a.) India, China, Korea and Thailand}

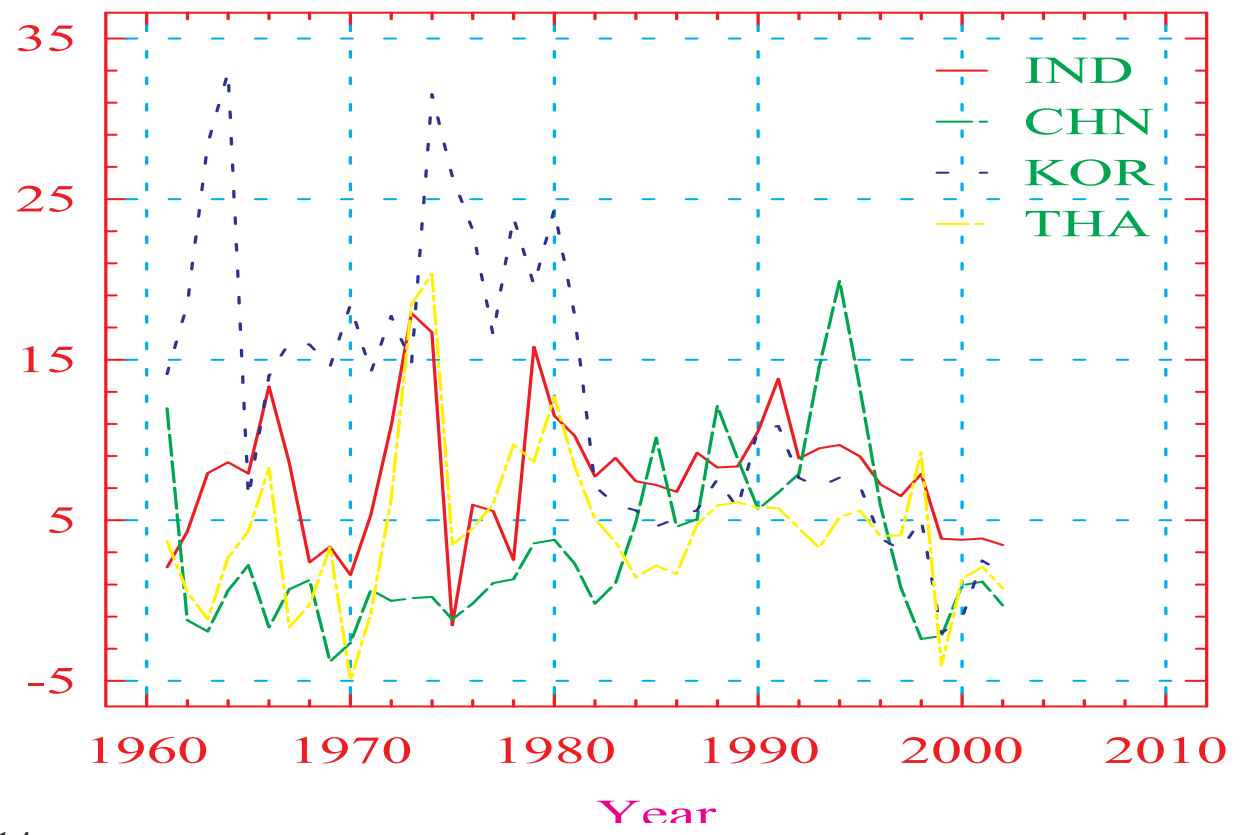

Fig. 14

Portfolio Investments /Exports of G,S\&I (India, China, Korea and Thailand)

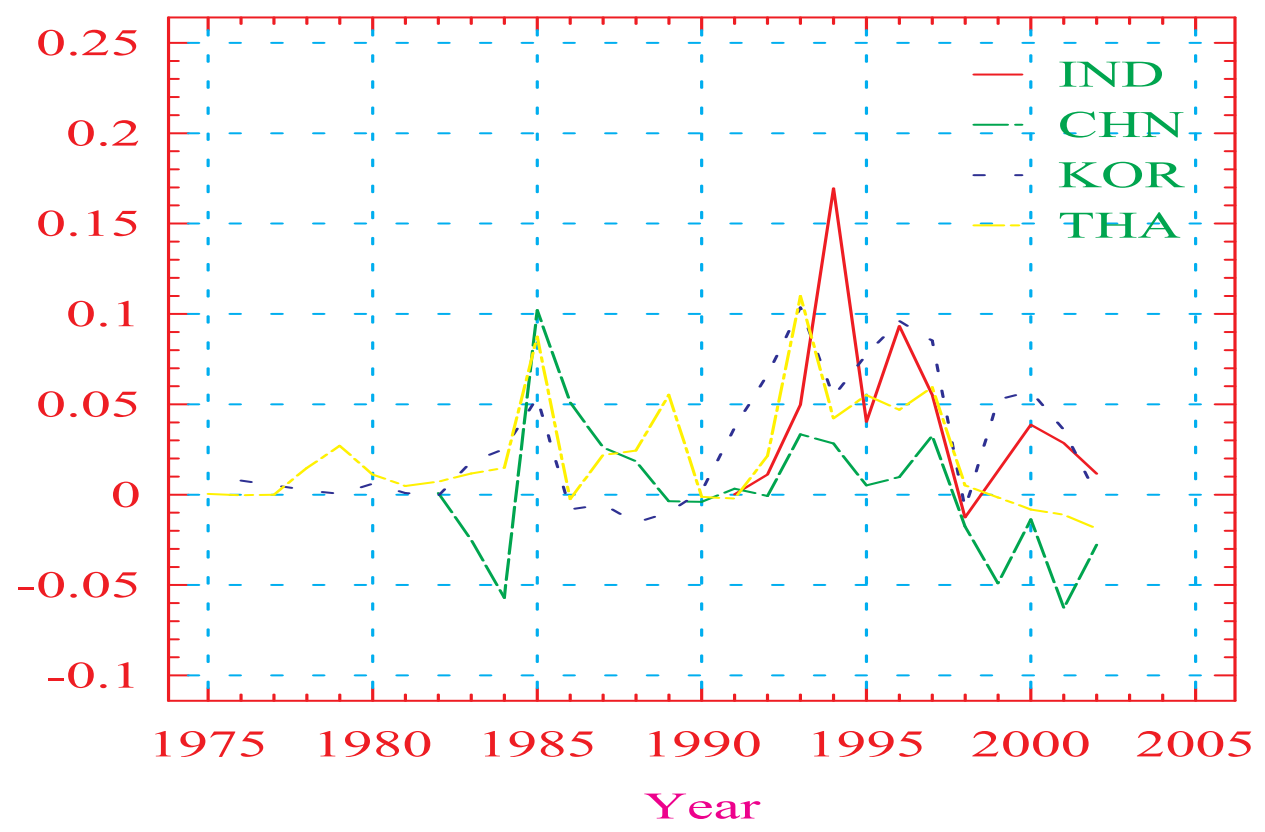


Fig. 15

Ratio of Exports to Imports (Mfgs.) (India, China, Korea and Thailand)

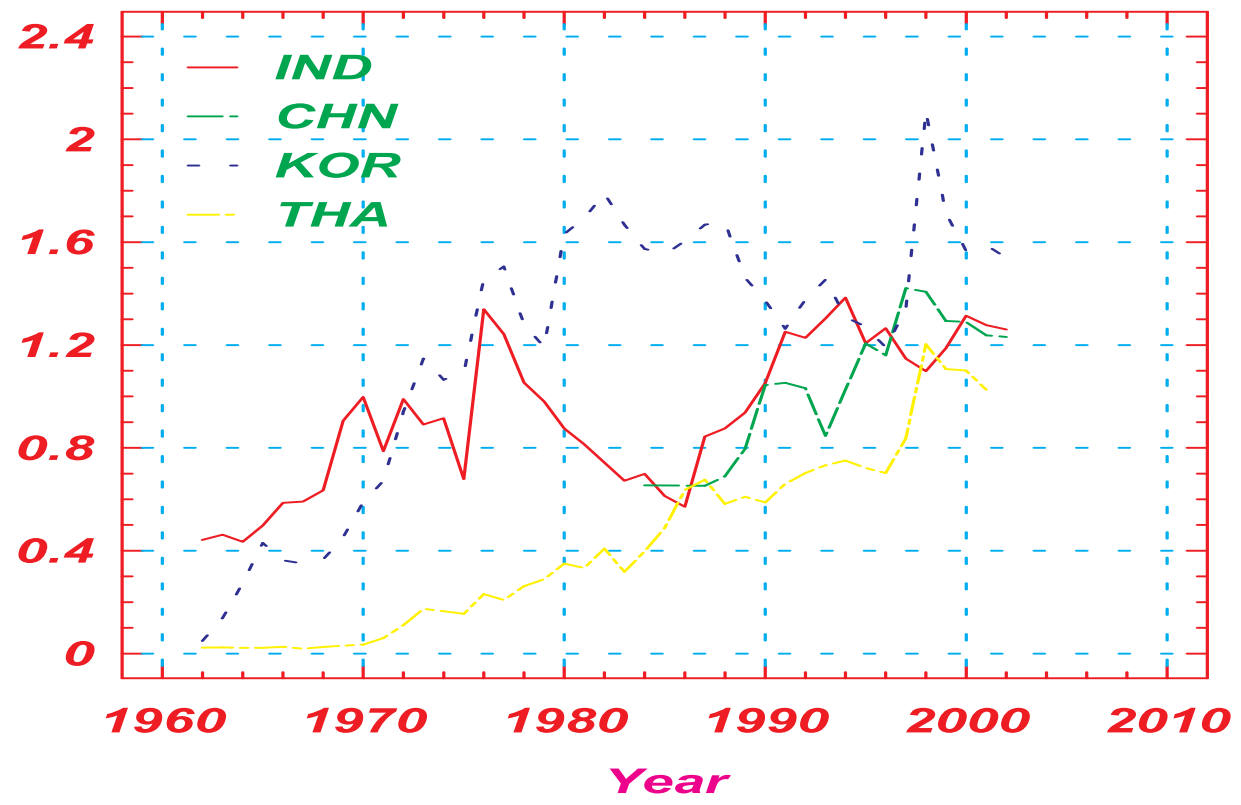

Fig.16

Ratio of Exports /Imports (Mfg-) (IND, CHL, ARG, IDN)

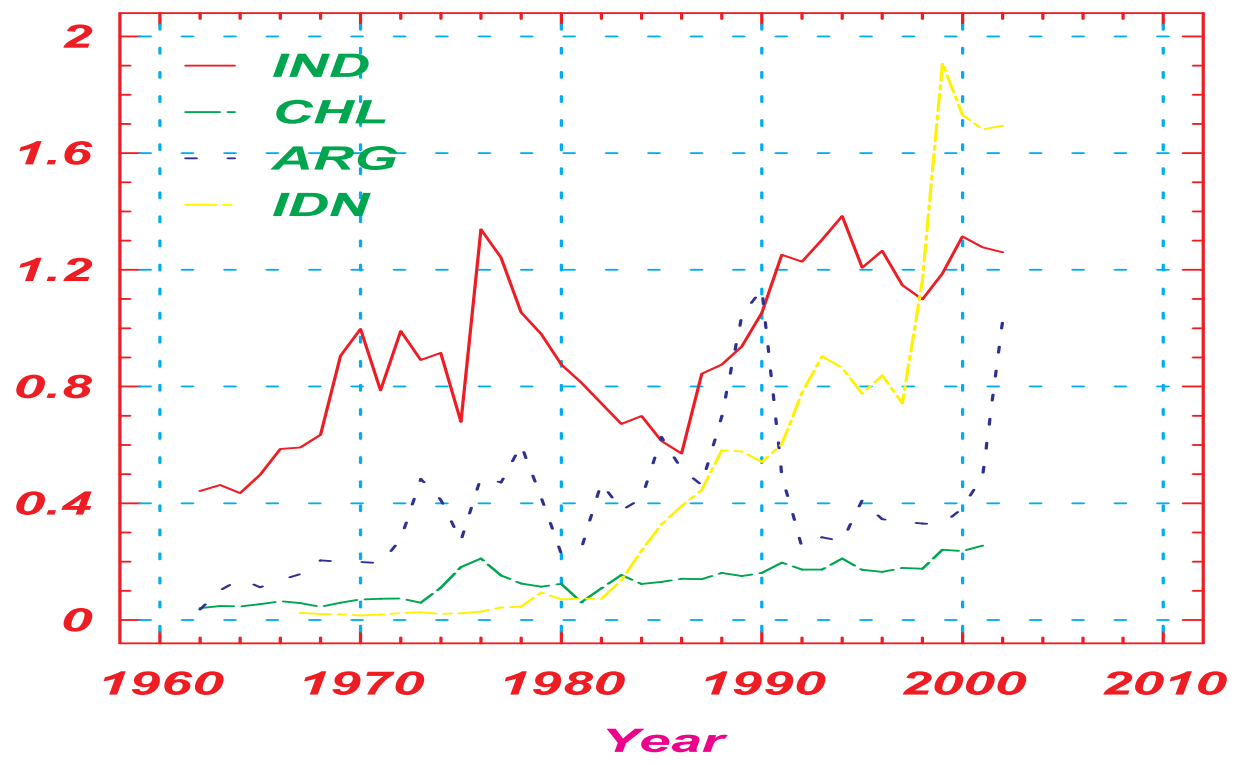

